Article

\title{
Loving My New Neighbor: The Korean-American Methodists' Response to the UMC Debate over LGBTQ Individuals in Everyday Life
}

\author{
Jeyoul Choi
}

check for updates

Citation: Choi, Jeyoul. 2021. Loving My New Neighbor: The

Korean-American Methodists' Response to the UMC Debate over LGBTQ Individuals in Everyday Life. Religions 12: 561. https://doi.org/ $10.3390 /$ rel12080561

Academic Editor: Kimberly Rios

Received: 11 June 2021

Accepted: 20 July 2021

Published: 21 July 2021

Publisher's Note: MDPI stays neutral with regard to jurisdictional claims in published maps and institutional affiliations.

Copyright: (C) 2021 by the author. Licensee MDPI, Basel, Switzerland. This article is an open access article distributed under the terms and conditions of the Creative Commons Attribution (CC BY) license (https:// creativecommons.org/licenses/by/ $4.0 /)$.
Department of Religion, University of Florida, Gainesville, FL 32611, USA; jeyoul777@gmail.com
Abstract: The recent nationwide debate of American Protestant churches over the ordination and consecration of LGBTQ clergymen and laypeople has been largely divisive and destructive. While a few studies have paid attention to individual efforts of congregations to negotiate the heated conflicts as their contribution to the denominational debate, no studies have recounted how post-1965 immigrants, often deemed as "ethnic enclaves apart from larger American society", respond to this religious issue. Drawing on an ethnographic study of a first-generation Korean Methodist church in the Tampa Bay area, Florida, this article attempts to fill this gap in the literature. In brief, I argue that the Tampa Korean-American Methodists' continual exposure to the Methodist Church's larger denominational homosexuality debate and their personal relationships with gay and lesbian friends in everyday life together work to facilitate their gradual tolerance toward sexual minorities as a sign of their accommodation of individualistic and democratic values of American society.

Keywords: homosexuality and LGBTQ people; United Methodist Church; post-1965 immigrants; Korean-American evangelicals

\section{Introduction}

The discourses of homosexuality and LGBTQ individuals in American Protestantism are polarized by the research that enunciates each denomination's theological stance and conflicts over the case studies of individual sexual minorities' struggle within their congregations. While some portray their dialogues in both the national and individual levels as greatly divisive and destructive (Fulton et al. 1999; Van Geest 2007; Griffith 2017; Haas 2002; Olson and Cadge 2002; Subhi and Geelan 2012; Wellman 1999; Wood and Bloch 1995), a few researchers have paid attention to the interactions between denominations and their congregations to report the subtle negotiation between them (Cadge et al. 2007, 2008; Rogers 1999). Resonating with this paucity, furthermore, no studies have articulated the first-generation Korean-American evangelical church's engagement in larger American denominational discourses of homosexuality and LGBTQ issues. In this article, I intend to fill these gaps in the literature through the case study, drawing on my ethnographic research on the Tampa Korean United Methodist Church (hereafter, the TKUMC), located in Wesley Chapel, Florida. ${ }^{1}$

The lack of research on sexual minorities in Korean-American immigrant communities is evident in the recent scholarship built upon the robust case studies on post-1965 immigrants and their religions, considered as "ethnic enclaves apart from larger American society" (Kim and Kim 2012; Kim 2015). While there has been no research conducted on firstgeneration Korean-American sexual minorities, some studies on 1.5 and second-generation Korean-American LGBTQ individuals have paid greater attention to the Korean-American immigrant community's diasporic characteristics that preserve the "oppressive" ethnoreligious culture for sexual minorities within the larger ethos of Neo-Confucianism and the conservative Christian theology. ${ }^{2}$ 
This current scholarship nicely affirms the robust scholarly efforts into elucidating what Won Moo Hurh and Kwang Chung Kim call "adhesive adaptation," which stresses non-Anglo-American immigrants' alternative integration to the United States without significantly losing their ethnicities in contrast to the old European model of assimilation (Hurh and Kim 1984; Kim and Hurh 1993; Warner 2001). Yet, how their actual acculturation takes place has remained unclear in relation to employing their changing religious experience (Choi 2021). Going beyond the discourse of the new immigrants and their religions as ethnic enclaves (Chen 2008; Di 2018), this article sheds light on first-generation Korean-Americans' evolving religious experience that accommodates the American values of individualism and egalitarianism presented through their responses to the recently augmented debate of the United Methodist Church (hereafter, the UMC) over the agenda of accommodating LGBTQ individuals into the denomination.

Like other mainline Protestant denominations such as the Episcopal Church, the Evangelical Lutheran Church (ELCA), and the Presbyterian Church of USA (PCUSA), the United Methodist Church has a long history of struggle to negotiate its conservative

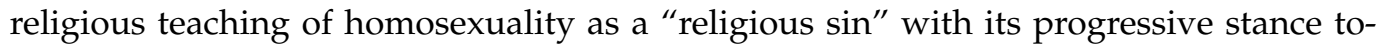
ward social minorities in the post-civil rights era (Rogers 1999; Wellman 1999; Wood and Bloch 1995). The Church's recent debate over permitting the ordination and consecration of LGBTQ individuals at the 2019 General Conference shows its continuing theological dilemma toward sexual minorities. While some white American congregations have left this issue up to the larger denomination due to local clergy's fear of schism, others such as the ELCA have conducted extensive group studies on the agenda to promote rational conversations and further alleviation at the congregational level (Cadge et al. 2007, 2008; Olson and Cadge 2002). The UMC's nationwide dialogue has similarly promoted the Tampa Korean-American Methodists' parochial theological conversation over homosexuality and LGBTQ individuals. Filling out the gaps in the literature between American Protestantism (Becker 1999; Roof and McKinney 1987; Smith 1998) and post-1965 new religious immigrants and their religions (Ebaugh and Chafetz 2000; Warner 2001), I contend that the Tampa Korean-American Methodists' continual exposure of the escalated denominational debate and of the personal relationships with sexual minorities in everyday life in which they incorporate the individualistic and egalitarian values of American society enables them to alleviate their polarized and intransigent theological positions over homosexuality and LGBTQ individuals. Through this case study of the first-generation Korean-American Methodists' response to the UMC's larger dialogue, in brief, this article hopes to demonstrate how the new immigrants participate in larger American society. In particular, my interest is to reveal that their changing religious experience, accommodating the new ethos of white American religious culture (Bellah et al. 1985), contributes to the mitigation of the heated, divisive, and destructive nationwide debate over homosexuality and LGBTQ persons at the congregational level (Cadge et al. 2007, 2008; Rogers 1999).

\section{The Recent Debate over Homosexuality in the United Methodist Church}

The special session of the 2019 General Conference (23-26 February), held in St. Louis, Missouri, was one of the most heated and divisive gatherings in the United Methodist Church over the agenda of the ordination and consecration of LGBTQ members. This debate, which has been going on since 1972, concluded a chapter by approving the "Traditional Plan" that enhanced the Church's present stance, which disapproved of sexual minorities' equal rights to heterosexual members, over the "One Church Plan", which posed to remove the restrictive and oppressive articles in The Book of the Disciplines of the United Methodist Church for LGBTQ clergy and members (Gilbert et al. 2019; Richey et al. 2010, pp. 221-22). As of February of 2021, the United Methodist Church is currently facing another crisis of a greater schism since some bishops who disagree with the consequence of the conference have proposed a new plan, called "Reconciliation and Grace through Separation" (Hodges 2020; Miller 2021). 
Although the TKUMC has not publicly made its official statement on it, this nationwide dialogue has not only caught the laity's attention, but also facilitated their parochial conversation over homosexuality and LGBTQ members at the congregational level. This section delves into how their theological views are polarized by the fundamental differences between the biblical interpretations of the Traditional and One Church Plans.

Since Iowa Bishop James Thomas made the denomination's first official statement of welcoming and acceptance of gay men and lesbians to local churches in 1972, the UMC has been involved in a theological dilemma where many Methodists' conservative reading of

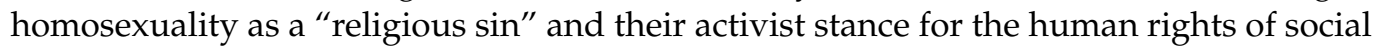
minorities were contradictory. ${ }^{3}$ No condonation or deprecation against homosexuality was made at the general conference before 1984. Without reaching any official agreements, pro-gay and lesbian members gradually cracked the denomination's vague definition of the Christian teaching of heterosexuality as the "image of God" in the post-civil rights era. Considering the "spirit of Wesley and Methodism" that nurtured diversity, they organized a United Methodist Gay Caucus to protect sexual minorities' equal rights in the denomination in 1975 (Richey et al. 2010, pp. 222-25). In contrast, some local conferences, which held the denomination's less vocalized belief that homosexuality was incompatible with the Christian teaching, occasionally put the clergy on trial and even defrocked some for officiating same-sex marriages or attempting to ordain gay pastors (Richey et al. 2010, pp. 222-25).

To resolve this escalation, the 1984 General Conference eventually clarified the denomination's official prohibition against the ordination of openly practicing homosexuals, saying, "Since the practice of homosexuality is incompatible with Christian teaching, selfavowed practicing homosexuals are not to be accepted as candidates, ordained as ministers, or appointed to serve in The United Methodist Church" (Richey et al. 2010, p. 246). At the same time, the meeting established the Reconciling Congregation Program that appointed some local churches to publicly welcome LGBTQ members as a remedy to the anti-homosexuality of the denomination (Richey et al. 2010, pp. 224-25). Unfortunately, these articulations never eased the debate over homosexuality, but instead offered extensive room for further disputes, where more clergy were excommunicated for officiating same-sex marriages and ordaining LGBTQ members, even as gay and lesbian ministers progressively emerged in the last three decades (Richey et al. 2010, pp. 248-49; Gilbert 2016a, 2016b).

The recent collision between the Traditional and the One Church Plans at the 2019 General Conference was one of the consequences of this greater and continuing division between the conservative anti-ordination and the liberal pro-ordination groups in the United Methodist Church. The Traditional Plan was proposed by the conservative party to strengthen the existing anti-ordination stance of the UMC. The plan suggested amending The Book of Discipline as follows:

Amend 415.6-Bishops are prohibited from consecrating bishops who are selfavowedhomosexuals, even if they have been duly elected by the Jurisdictional or Central Conference. Bishops are prohibited from commissioning, those on the deacon or eldertrack if the Board of Ministry has determined the individual is a self-avowed homosexual or has failed to certify it carried out the disciplinarily mandated examination, even if the individual has been recommended by the Board of Ordained Ministry and approved by the Clergy Session of the Annual Conference ... (Mainstream UMC 2019, p. 70)

This proposed amendment aimed to prohibit further denominational consecration of gay men and lesbians by restricting the local autonomy of each clergy and conference. The plan also inserted the article of penalty for transgression of the amended rule.

Amend 613.19-Every Annual Conference shall certify that the bishop has nominated only members of the Board of Ministry who will uphold, enforce and maintain The Book of Discipline related to ordination and marriage of 
practicing homosexuals. Failure to do so shall result in The General Council on Finance and Administration withholding all funds from the United Methodist Church and withdrawing the annual conference's ability to use the denominational cross and flame logo. (Mainstream UMC 2019, p. 70)

Considering that this present denominational position towards homosexuality and LGBTQ members would not protect the equal rights of LGBTQ clergy and members, and inevitably cause a larger division of the UMC, the progressive group instead proposed the One Church Plan to seek reconciliation. It enlarged the agency of local churches and ministers on homosexuality and LGBTQ ordinations. The plan first suggested removing the current restriction on marriage between people of the same sex.

Amend 161. G-We affirm that sexuality is God's good gift to all persons. We call everyone to responsible stewardship of this sacred gift. Although all persons are sexual beings whether or not they are married, sexual relations are affirmed only with the covenant of monogamous, marriage between two adults ... All persons need the ministry of the Church in their struggles for human fulfillment, as well as the spiritual and emotional care of a fellowship that enables reconciling relationship with God, with others, and with self. (Mainstream UMC 2019, pp. 20-21)

It also attempted to broaden various interpretations on human sexuality in the qualifications for ordination.

Amend 303.3-The responsibility for determining how standards, including standards related to human sexuality, may apply to certification or ordination in a given annual conference falls to the Conference Board of Ordained Ministry and the clergy session of the annual conference. The bishop may choose to seek the non-binding advice of an annual conference session on standards relating to human sexuality for ordination to inform the Board of Ordained Ministry its work. (Mainstream UMC 2019, pp. 20-21)

Finally, the amendment proposed augmenting the authority of each minister's conscience in his or her practice of religious rituals as follows:

340.3 a.-Each clergy shall have the right to exercise his or her conscience when requested to perform such marriages, unions or blessing as a matter of his or her individual religious liberty. b. In conferences where civil law permits a pastor to perform same-sex marriage services, no clergy shall at any time be required or compelled to perform, or prohibited from performing, any marriage, union, or blessing of same-sex couples, or of any couples. (Mainstream UMC 2019, p. 22)

This essential difference between the Traditional and One Church Plans traces back to their opposing viewpoints of homosexuality presented in the traditionalist and revisionist debates in the 1970s and 1980s. The traditionalists understand the Bible as the "eternal truth" over human knowledge and reason, stating that homosexuality is a religious sin, with their biblical literalism based on Leviticus 18:22 and Romans 1: 18-32 (Fulton et al. 1999). Some in this group allegorically interpret the homosexuality mentioned in the Scripture as a contradiction to "God's natural law", evident in Genesis 1 and 2 which depict procreation as the purpose of human sexuality (De Young 2000; Jones and Yarhouse 2000). In contrast, the revisionists refuse this traditionalist view through their understanding of the Bible as a "human document inspired by God" (Rogers 1999). Instead, they believe that interpretations of the biblical passages cited by their opponents are subject to the contemporary context where they understand homosexuality as an object of embrace through God's holistic grace of His people (Balch 2000; Grenz 1998; Wink 1999).

While this debate over homosexuality and LGBTQ issues taking place in the United Methodist Church, in particular, serves as a civil society that contributes to gathering scattered opinions of the public into the national level (Wood and Bloch 1995), scholarship identifies the lack of research on the interaction between the denominational dialogue 
and individual congregations (Cadge et al. 2007, 2008). In addition to the UMC's ambivalent position toward homosexuality, the vast majority of clergy in local churches is highly reluctant to bring the larger debate into, or make an official statement in, their congregations, where the issue might cause a schism (Olson and Cadge 2002). Similarly, most Korean pastors in the Korean United Methodist Church Association perceive some of their members who bring the agenda to their council meetings as "dissenters" who attempt to cause a division in their congregations (Kim 2018). Nonetheless, the UMC's larger dialogue has caught the attention of the Korean-American Methodists in the Tampa church. Resonating with the severe gap between the Traditional and One Church Plans, they hold their own intransigent theological positions, polarized by the traditionalist and revisionist perspectives over homosexuality. As Myeongsuk, who strongly opposes the One Church Plan, states:

The Bible disallows sodomy [namsaek] in the story of Sodom and Gomorrah. That's a sin, which we cannot accept in the church. If we really think that it's a sin, we should not even have those homosexuals in our church. I'm sure that those homosexuals who are already in the church never really think that they are wrong. Who knows what they think of it and what they do with their partners? So, we need to let them repent first and then we could let them in ... Those who believe that it's okay to have them as laypeople in the church or even allow their ordination are very problematic because they understand the Bible in their own way. That's sort of theological liberalism, including biblical criticism! God never allows us to do such a thing. ${ }^{4}$

Myeongsuk holds one of the most conservative theological stances grounded in biblical literalism and inerrancy among the traditionalists, who largely disapprove of homosexuality as a religious sin which should not be accepted by Christianity. ${ }^{5}$ Minjun, another traditionalist, instead reads the Scripture allegorically for a rational conversation with revisionists over the issue:

I do not bring specific biblical passages to explain why homosexuality is religiously wrong. Those who support gay and lesbian rights don't understand the passage of Sodom and Gomorrah as a reference to God's prohibition of homosexuality. Instead, I bring the creation story of God to explain heterosexuality as His model for procreation. In this way, it is much easier to convince those homosexual couples that they can't bear life and why homosexuality is a sin from the Christian perspective ... ${ }^{6}$

Minjun's allegorical understanding of the Scripture attempts to demonstrate that homosexuality is a religious sin because it goes against God's natural law of human sexuality, whose purpose is procreation (Jung 2020, pp. 11-13). Hyeonjeong perceives the debate over homosexuality in both the denomination and larger American society as a "threat" to her conservative theological belief of the Bible as the "timeless truth", whose social and cultural influence has been "lost" in the new society. ${ }^{7}$ Although she accepts some scientific fact posed by her theological opponent, Hyeonjeong believes that knowledge and science could never predominate over the authority of the Scripture:

I love America, but not those Democrats who have screwed the country. They passed the law that protects the right of homosexuals and now churches are facing this problem. Making laws is very important to create a religiously good culture. Some people say that homosexuals are born in that way and others might feel a kind of homosexuality when they grow up. However, their feelings may not be permanent. If we make a law to protect the right of homosexuals, those kids in the temporary stage would easily solidify their homosexual identity because the law already grants that it's not a bad thing! This is really problematic. That evil law is corrupting God's given culture in this land ... ${ }^{8}$

In brief, some traditionalists of the Tampa church strongly oppose the One Church Plan using their conservative reading of the Bible as the "eternal truth" over human reason 
and knowledge. In both their biblical literalism and allegorism, homosexuality is a greater sin as a "threat" to the heterosexual culture as "God's ideal model" (Jung 2020).

Indebted to the growing influence of religious individualism (Wilcox 2002), in contrast, the revisionists of the Tampa church understand the Bible as a "human document inspired by God" that needs more revisions and interpretations varying in the contemporary context where they incorporate new scientific findings and personal experiences. They all believe that Christianity should not only accept homosexuality and LGBTQ individuals but also grant their equal rights in the church. As Seongsu says:

Many other church members really believe that the Bible is the ever-changing truth so that we have to believe everything it says literally. That's not true. There were some things written like 2000 years ago. Some of the things are wrong! It's not good to believe that we have to believe everything because the Bible was written in that way ... ${ }^{9}$

Seongsu first clarifies that the Scripture is not the "eternal truth," and it might have some "incorrect information" given new scientific knowledge. In particular, he argues that its description of homosexuality needs revision based on new scientific evidence found in contemporary society. He continues:

For example, people had no idea what homosexuality was when the Bible was written, but now we do have a much better understanding of it. Many people in the church believe that it is a religious sin just because the Bible says that, but that's not true. When we grew up most of us underwent a kind of the homosexual stage as a part of mental development. People don't know about this. Moreover, they don't understand that there are many different types of homosexuals either. They just put all of them into one basket as sinners ... What I am trying to tell you is that homosexuality is not a sin because it's not a choice, okay? Other European churches all accepted it. (see Note 9)

For Seongsu, the traditionalist belief that homosexuality is a religious sin is an outcome of their "lack of understanding" of the scientific findings largely omitted in the Scripture. Dongjin similarly insists that homosexuality is not a religious sin by drawing on his own interpretation of the Scripture and experience with sexual minorities:

Personally, I think that homosexuals are born in that way, not by choice. The majority of them were born in that way. I thought about me kissing a guy. Why would I want to do that? Some people even want to have surgery? Why would I want to do that? But, some people kill themselves because they are desperate to do these. So, I get that they were born in that way and I accept them as they are ... I don't think that homosexuality is a sin either. In terms of what the Bible says, it is a sin if you are a straight male who wants to try homosexual intercourse ... I have no problem with homosexual ministers. ${ }^{10}$

In short, the United Methodist Church's ongoing debate over homosexuality stimulated the Tampa church laity's parochial conversation over the issue in promoting them to articulate their own theological stances polarized by the Traditional and One Church Plans, grounded in the essential difference between the traditional and revisionist interpretations of the Bible. Despite the larger discrepancy between the denomination and each congregation, the Tampa Church's divisive theological positions resonates with the UMC's historical dilemma toward homosexuality, caused by their conservative interpretation of human sexuality and progressive Wesleyan tradition. The next section continues to explore how the Korean-American Methodists' polarized theologies are further intermediated by the larger dialogue of the UMC, anchored in the American values of individualism and egalitarianism. 


\section{The United Methodist Church as Negotiator of Intransigent Theologies}

As seen in the last section, the Tampa church's affiliation with the United Methodist Church differentiates its laypeople's American immigration experience from other KoreanAmerican evangelicals who belong to independent ethnic religious communities from the mainstream U.S. society (Warner 1993, 2001). Unlike these majority immigrant evangelicals, the Tampa Korean-American Methodists engage in larger American society, in particular, through the UMC's recent debate over homosexuality. As Hyeonju states:

Coming to this Methodist church has pros and cons. I chose to come to this one because I was so tired of other Korean immigrant churches where the senior pastor had excessive power. There were so many unclear things going on within their finance. I don't have to suffer from that kind of problem in this church, owing to its democratic system. However, this UMC system also has cons where we need to deal with some unnecessary debates because we need to listen to people's opinions, not merely God's voice. The current issue over homosexuality is one of the examples. If we were only a Korean church, we would have not even talked about it unless the pastor said something about it. But, this is not the case in this church ... ${ }^{11}$

Hyeonju, who is more used to the Korean religious culture, where the senior pastor holds a greater power over the congregation (Choi 2021, pp. 55-60; Jung 2020, p. 13), believes that the UMC's democratic system is more likely shaped by larger "voices of people" than "God's voice." Although admitting the new system's advantage of preventing the senior pastor's "corruption", she is concerned about the "danger" of engaging in larger society that might neglect the "voice of God". Hyeonju's statement paradoxically demonstrates that its denominational affiliation, in particular, through the debate over homosexuality, serves as a window for the Tampa church to engage in larger American society.

Seonyeon is more accepting of this UMC's communicable system than Hyeonju, still proving that the dialogue over homosexuality is a worthy platform for the Tampa church to be involved with the larger U.S. society that "God is working through."

Well, I was very impressed by how the UMC dealt with the issue of homosexuality. I was convinced that God truly worked through this good [democratic] system and did not give up on this world. The situation was bad because the One Church Plan was predominant over the Traditional one. Actually, it turned out well. The process where we all gather and seek God's will together, not relying on merely one leader showing off his ability, is very good. Some people might say that it's kind of tedious and unnecessary, but I believe that that's how we seek out God's will together ... ${ }^{12}$

Not only do Hyeonju and Seoyeon see the influence of the UMC in moving the congregation to engage in what had previously been a non-negotiable theological issue, even the traditionalist senior pastor Hong Gimin's opposition to sexual minorities rights has been moderated by his concerns over a possible schism within his church over this issue (Van Geest 2007; Olson and Cadge 2002; Wellman 1999). A month before the 2019 General Conference, the pastor wrote a series of weekly columns that reveal his awareness of the ongoing debate and its possible consequences for his church. In one column, he had this to say:

Recently the UMC has been polarized over the issue of permitting ordination and same-sex marriage of homosexuals by the One Church Plan and the Traditionalist Plan. The first option is relatively convincing to pass because many influential bishops support it, although most Korean United Methodist churches endorse the second one ... Some Korean ministers have organized a task force to raise their voices to the issue, yet it is not enough to change the current dominance of the One Church Plan ... ${ }^{13}$ 
Although he predicted the predominance of the One Church Plan over the Traditional one, Pastor Hong was reluctant to attack the revisionists for fear of schism:

How should we respond to it then? Some people might say that we should be prepared to leave the denomination in the case where the first option [the One Church Plan] is approved. However, it is not a simple decision to give up all of our property in the denomination. Even if the One Church Plan is put in place, each church will have their own right to choose their theological stance toward homosexuality. No matter which plan is passed, it is more reasonable to predict that our church may stay in the denomination. Please do not debate over this issue that might disturb our community in your meetings, but put your efforts in praying for God's right decision .... . (see Note 13)

For Pastor Hong, the threat of schism and division of church property was a greater concern than forceful opposition to LGBTQ individual rights. Moreover, despite his opposition to homosexuality, the pastor asked his congregants to see sexual minorities as sinners in need of God's love:

Meanwhile, God's church should embrace homosexuals through His love within its community that encourages them to accept homosexuality as a sin and to be born again. This is one of the reasons why His church exists in this world. Jesus kindly became a friend with tax collectors and other sinners. In Luke 5: 31-32, He also said, "It is not the healthy who need a doctor, but the sick. I have not come to call the righteous, but sinners to repentance." Only He knows what is going to happen to His church. He is going to take care of this issue ... Let's repent and pray about it. (see Note 13)

The overall tone of Pastor Hong's columns showed that he subtly endorsed the Traditional Plan consistent with his traditionalist viewpoint toward homosexuality. Yet, his greater concern of a possible schism within the congregation and subsequent division of church property led him to accept homosexuality as sinful behavior in need of God's love.

Pastor Hong's political decision to continue to condemn homosexuality yet accept the sinful behavior in order to avoid schism did not sit well with some of the traditionalists. As Hyeonju states:

Well, it's a relief to see that the denomination didn't take the One Church Plan. However, Pastor Hong's columns worried me a lot. He didn't take any strong actions against the One Church Plan but only said that we may not leave the UMC even if it would be taken. What if the result had turned out differently, what should I do ... ? I think that homosexuality is not a debatable issue because God says that it's a sin. But, this church and the denomination are already debating it. I don't really understand how this has even happened. This is already very secular [corrupted] ... (see Note 11)

Hyeonju perceives that the pastor's equivocal position transformed a theological problem into a debatable and political one. Myeongsuk, another traditionalist, similarly complained as follows:

Pastor Hong has treated this issue politically. This is a very serious spiritual problem. Whenever some members, including myself, suggested our church to speak up with a strong voice against the One Church Plan in the council meeting, he always made us keep quiet on that issue, treating us like agitators ... He recently wrote some columns, saying that it is not easy to leave the denomination because of the laity's property in it. Yes, people may not want to give up theirs easily, but the pastor himself doesn't want to leave his stable salary and pension behind either. He needs to repent for his faithlessness too. He has already negotiated with this corrupted denomination because of his secular desire. It is already wrong to try to compromise with the sin! (see Note 4) 
In contrast, Sukja, one of the revisionists, disapproved of Pastor Hong's opposition to homosexuality yet welcomed his political decision to not force gay men and lesbians out of the church:

I saw and learned about homosexuality. I also know why many Korean churches disagree with the One Church Plan. They don't fully understand what homosexuality is, and don't want to know what it is. I think that they are bringing some religious reasons to this political issue to keep their own interest. Korean pastors are just afraid of losing some laypeople who would leave disappointed by the church's decision. This would severely hurt their occupation [bapjul], right? Other Methodist churches in New York have already presided over same-sex marriages. What's the matter religiously? ${ }^{14}$

In short, the church's affiliation with the United Methodist Church, resonating with the larger ethos of individualism and egalitarianism, inevitably turned the issue of homosexuality from a "timeless religious sin" into a "debatable political problem" for Tampa's Korean-American Methodists. Their affiliation with the national United Methodist Church led them to debate a formerly settled theological issue and, in this process, they became familiar with and accommodated moral debates over LGBTQ individual rights under discussion in the larger society. This accommodation of the tumultuous, individualistic, and democratic values of the new society was further influenced by church members' personal experiences with sexual minorities.

\section{Loving My New Neighbor}

Despite the dramatic rise of LGBTQ movements in the post-civil rights era, antihomosexuality characterized America's 1970s and 1980s. Its sturdiness was gradually assuaged in the mid-1990s, where people eventually began to recognize LGBTQ individuals as social minorities through society's ongoing discourse of homosexuality and experiencing them as their friends or family members in everyday life (Loftus 2001; Yang 1997).

LGBTQ individuals were also largely unknown to most Korean-American Methodists in their pre-migration stage in South Korea, maintaining a larger impact of the conservative Christian theology and Neo-Confucianism that stressed a robust in-ethnic heterosexual marriage as its religious and cultural norm for familial prosperity and values (Chung et al. 2006; Han 2000; Jung 2020; Rhee 2006; Yi et al. 2014, 2018). In addition to the denominational affiliation, however, their gradual encounters and closer personal relationships with sexual minorities through their American friends, U.S.-born children, and church members in their immigrant lives helped them to negotiate their intransigent and polarized theological stances by incorporating egalitarian values.

Korean-American Methodists first came across gay men and lesbians as sexual minorities in the United States in the 1970s. Dongjin's following statement resonates with the country's larger homophobic sentiment during this time:

I first heard of homosexuality when I was in high school in the mid-1970s. People around me made fun of it a lot. We were young and didn't really know what it was exactly. I also thought that homosexuals were disgusting. I was listening to the radio. A guy came on and was talking about a pornographic scene where two guys were kissing on their lips. I was like, why were these guys doing that? (see Note 10)

Like most Americans, LGBTQ people are largely unfamiliar to Korean-American Methodists in the post-civil rights era. Yeongsik recalled his first encounter with a SpanishAmerican gay person as follows:

It was 1972 when I was thirty-two. After my work, I was walking alongside the coastline of West Tampa to get home. A red mustang stopped and opened the door for me. A tight-looking Spanish-American guy in the car said, "you need a ride?" I thought that he was very kind and looked like he lived nearby my place. We drank a bottle of beer and hung out at his place. After a while, he asked me 
to take a shower together. I didn't know that he was gay because I had never seen homosexuals before and no idea about who they were. But, I instinctively noticed that it was a very weird call and gave him an evasive answer so I could leave. I told this story to my niece's husband, who was white-American, and he just died laughing, saying "how much did you get paid for it?" I finally realized that that guy was homosexual ... 15

Yeongsik's first time coming across an American gay person largely perplexed him, coming from South Korea, whose religious culture is grounded in in-ethnic heterosexual marriage. Sukja tells a similar story to Yeongsik's:

I encountered some lesbians when I worked as a counselor in the 1980s. A couple of women approached me for some reason. I didn't know what that meant at that time, but I do now. One of my colleagues was laughing and told me that they were lesbians. I asked her, "didn't they know I was married and had kids?" She replied to me that "why did they care? They just tried it anyway." (see Note 14)

Most of Tampa's Korean-Americans first encountered gay men and lesbians as sexual minorities, an unknown group of people, in the United States of the 1970s and 1980s, a society predominated by anti-homosexuality.

In addition to the denominational affiliation with the UMC consistently exposing them to the national issue, the Tampa Korean-American Methodists lessened their antihomosexuality grounded in their robust theological conservatism through their immigration experience, where they encounter sexual minorities through their friends, children, and church members in their ordinary lives. Putting aside their conservative Christian worldview, which sees homosexuality as a "threat" and "religious sin," the Tampa traditionalists in particular gradually sought a middle ground between the Traditional and One Church Plans of the United Methodist Church. Their negotiation resonates with the long-lasting ambiguous attitude of the UMC and Pastor Hong toward homosexuality and LGBTQ persons in the praxis of their conservative theology within the larger democratic society.

Haeun, holding a traditionalist viewpoint toward homosexuality as a religious sin, states:

I didn't even have any chances to meet homosexuals in person because the Korean culture didn't accept them as much as here. In my graduate school in this country, however, nearly half of the male students are openly gay. I didn't really like them at first, just because I didn't know much about them. As I hang out with them more, I have realized that they are just normal people like us ... 16

Born and raised in South Korea, Haeun came to the United States for her graduate education in 2012. Like the preceding Korean-American Methodists, she rarely encountered any LGBTQ individuals in Korea. However, her experience of sexual minorities demonstrates an improved perception of LGBTQ people in the larger American society of the 2010s. Though holding a traditionalist perspective of the Bible as the timeless truth, this changing social and cultural stream opening to the LGBTQ community allowed her to articulate her own criticism of Christianity's conservative interpretation of homosexuality. Haeun continues:

Many Christians are so upset about homosexuals just because the Bible says that it's a sin. But, I don't understand why they are particularly singling out homosexuality from all other kinds of sins. How many Christians could confidently say that they are religiously better than homosexuals are? The church community already lies and hates each other. Didn't those "sinners" crucify Jesus on a cross two thousand years ago? I think that this logic still applies to the homosexual issue. People want to hide their sins by accusing those sexual minorities. They should know that the church is already a place of sinners ... (see Note 16) 
Having personal relationships with sexual minorities within the more open cultural environment of U.S. society cracks Haeun's conservative theological stance toward LGBTQ people. Jiwon, another traditionalist who has gay friends, was hesitant to accuse sexual minorities as "sinners."

Well, the debate over homosexuality has made me struggle a lot because I do have many gay friends. I know that we have to believe the Scripture as it is somehow. But, I don't have a clear answer if homosexuality is a sin or not in terms of what the Bible says. Because interpretations vary with each individual. Some people understand the story of Sodom and Gomorrah as a reference to God's accusation of homosexuality. But, I think that that is just about His warning against sexual corruption in general. And some Christian denominations have already accepted homosexuals as laypeople or clergy. In my experience, they are just normal people like us ... ${ }^{17}$

Jiwon's personal relationship with gay friends challenged her biblical literalism. Like Haeun, her experience of larger American society opens the door for biblical allegorism toward homosexuality. This point is also evident in Minjun's following statement:

Although I believe that heterosexuality is the ideal image of God's sexuality, Christianity will eventually have to embrace homosexuals. I feel like we are undergoing a long and difficult process to accept them in our religious worldview like the racial issue in this country of the 1960s. I do have gay friends and have talked about this current debate. We understand each other's stance. I would welcome them if they want to come to our church now. Perhaps later it will be okay for us to have gay or lesbian ministers. This might really happen. Who knows? Now, churches are against them because many members are not ready for it ... (see Note 6)

Minjun still believes that the purpose of human sexuality is procreation grounded in heterosexuality, according to "God's natural law." Having gay friends, however, he modified his position gradually toward a revisionist perspective that understands the issue of homosexuality as part of the history of the human rights movement in the United States.

Other members holding a traditionalist view similarly take a negotiable stance with a revisionist perspective, as their U.S.-born children challenge their conservatism. As Jeongja says:

I have struggled with my daughter who was hurt by the church ... She used to go to an American church, but eventually left it because of its members' antihomosexual demonstration. She told me that they should accept homosexuals if they are true Christians. God also created them as they were, but the church excluded them ... Well, I didn't know the answer to what she said. All I could do was read the Bible and pray to God about it. Now I think that we can't still accept homosexuality itself because the Bible says that it's a sin. But, we should accept those people in the church. Because we are all sinners who strive for God's salvation. I think that homosexuals are just like us who try to get out of sins ... 18

Perhaps Jeongja would disagree with the One Church Plan that grants LGBTQ members' ordination and marriage within the denomination, yet her daughter's challenge toward conservative Christianity's anti-homosexuality pushed her to accept sexual minorities as the "same kind of sinners" as heterosexual members in the church (Jung 2016, pp. 6-7). Angela, one of the traditionalists, reached a similar conclusion to Jeongja through her conversation with her second-generation son.

My son, Aron, has some gay friends in the church and school. He said, "God loves everybody, but why not homosexuals?" I said, "Yes, He does, but made us by perfection, right? In the Bible, men and women get together. So, if a man likes a man or if a woman likes a woman, this is not the image of God. 
Because God does not make any mistakes. We need to love and treat them with love. This doesn't mean that what they are doing is right. Just like a robber who stole something from a supermarket. I don't agree with what he did, but can understand why he did it and love him as a church member ... "I mean, considering them as sinners doesn't mean that they should be discriminated against in the society either ... ${ }^{19}$

Like Jeongja, Sophia did not revise her traditionalist viewpoint of homosexuality as a sin. Through a conversation with her son, however, she moved towards a revisionist perspective, wherein she accepts sexual minorities as equal members and citizens to heterosexuals in the church and in society. Sukja's revisionist theological position is also mediated by her experience of larger American society:

Many Christians say that it [homosexuality] is a sin. I am not sure how difficult it is to accept homosexuals as normal people like us, but society is already changing. How many homosexuals are out there? It's not a problem for those who were born and raised in this country. My kids have homosexual friends, who used to come over to our place back in the day. I am totally okay with them ... If allowing ordination is too much, I really hope that our church members would someday reach a stage where they openly accept homosexuals as laypeople in the church where we can shake their hands and have lunch together ... (see Note 14)

As well as through the denominational affiliation of their church, the Korean-American Methodists engage in the ongoing discourse of homosexuality and LGBTQ issues in larger American society through their U.S.-born children. Their conversation helps some traditionalists of the church to have a relatively inclusive and tolerant attitude toward sexual minorities, compared to discussing them as a theological object.

Actual encounters with LGBTQ individuals as their church members further pushes these Korean-American Methodists to materialize their gradually opening, yet abstract, discourse of homosexuality and LGBTQ issues in their church lives. As Hyunju, another traditionalist, says:

When I attended a Korean church in Seattle, I had a male elder who suffered from a kind of mental disease after he got divorced from his wife. A few months later, he showed up wearing a female outfit and makeup. He seemed to change his sexual identity. I was sitting next to him and trying to talk to him. It wasn't easy because I had never encountered those people. The current issue over homosexuality makes me think of him and asks me, "What should I do for those people in need as Christians? How should we change to embrace them in Christ?" (see Note 8)

Although Hyeonjeong holds a robust traditionalist view of homosexuality as a religious sin and threat to the Christian worldview, the actual encounter with LGBTQ members in the church asks a practical question of how to negotiate her intransigent theology with a revisionist perspective that embraces sexual minorities through God's love. Angela's incident with another family, whose child was gay in the Tampa church, prompted her to ask a similar question to Hyeonjeong and further challenged her conservative theological attitude toward homosexuality:

A few years ago, my family was involved with a huge conflict with one of the families in the church. Their son said that he is gay in the youth meeting, but his parents misunderstood that my son spread it as a rumor to other kids. They started hurting my family and me. I was so upset and couldn't control my anger toward them. Other church members tried to calm me down, saying "that's not your fault, but theirs." In the reconciling meeting, I finally exploded in anger toward them saying, "I'm gonna literally kill you and go to jail happy!" They said, "we were just upset about our son being gay!" I said, "I'm sorry about your situation, but that's not our problem!" At this moment, the Holy Spirit just 
came to me immediately and my anger just turned down. I felt really sorry for them if I had made their pain worse because most members were on my side and this family felt marginalized. So, my husband and I apologized to them ... (see Note 19)

Angela further confesses that her anger toward the family relied upon her unconscious "spiritual supremacy" as a "normative heterosexual" through her personal prayer:

When I was struggling with that issue, I complained to God about it, saying,

"God, I just hate them and don't understand why you still let them come to the same church that I go to." Then, He said, "you come to me too." That was one of the biggest aha moments. I unconsciously thought that I was the innocent one by blaming them as sinners. They had a gay son and perhaps mean personalities ... However, when God told me that they also came to Him as I do, I realized that He loved them and me equally. And I was not better than them, but maybe worse. I can't explain how shameful I felt when I realized that ... (see Note 19)

This incident shows that the actual encounter and relationship with LGBTQ members in the church further required Angela to negotiate with a revisionist viewpoint that fully grants the equal rights of sexual minorities in the praxis of her gradually opening conservative theological position.

In a nutshell, Tampa's Korean-American Methodists' encounter and form personal relationships with LGBTQ people through their friends, U.S.-born children, and church members, which inevitably pushes them to take a negotiable stance toward homosexuality and LGBTQ individuals. This American immigration experience assuages the Tampa church's polarized and intransigent theologies toward the discourses of homosexuality and LGBTQ issues. In addition to their consistent exposure to the national dialogue through the United Methodist Church, the Korean-American Methodists' gradual acceptance of LGBTQ people in everyday life as a sign of lessening their robust theological conservatism reveals their accommodation of the larger U.S. society.

\section{Conclusions}

The debate over the agenda of accommodating sexual minorities in the national context of the United Methodist Church looks like a divisive, destructive, and persistent force in the fundamental theological difference between the traditionalist and revisionist biblical interpretations (Fulton et al. 1999; Griffith 2017; Haas 2002; Olson and Cadge 2002; Subhi and Geelan 2012; Van Geest 2007; Wellman 1999; Wood and Bloch 1995). Yet, shedding light on the actual interactions between the denomination and individual congregations instead offers an alleviated snapshot of the dialogue (Cadge et al. 2007, 2008; Rogers 1999). This article has attempted to push forward this recent scholarly effort by drawing upon the case of Tampa's Korean-American Methodists as an ethnic minority group in the post-1965 era who have been neglected in the discourse of American Protestantism (Becker 1999; Roof and McKinney 1987; Smith 1998).

Unlike the vast majority of first-generation Korean-American evangelicals, seen as diasporic entities separate from the mainstream U.S. discourse (Kim and Kim 2012; Kim 2015), Tampa's Korean-American Methodists engage in the national discourses of homosexuality and LGBTQ members through their affiliation with the United Methodist Church that promotes their conversation on the topics at the congregational level. While this national dialogue facilitates the laity's ability to articulate and further polarize their theological stances toward homosexuality and LGBTQ individuals, the Tampa church's consistent exposure to the denominational debate, ironically, turns this "non-negotiable theological issue" into a "contentious political one." The Korean-American Methodists' everyday lives in which they encounter sexual minorities additionally push some traditionalists of the church to accept the abstract theological discourses as a matter of the everyday politics that requires greater tolerance toward LGBTQ individuals (Jung 2016). These American immigration experiences, shaped by both the denomination's national dialogue and every- 
day life, consequently lessen the church's polarized and intransigent theological positions anchored in the traditionalist and revisionist biblical interpretations.

Rejecting the old European model of assimilation, scholarship on post-1965 immigrants and their religions has pointed out that their assimilation has taken an alternative path where they do not have to lose their ethnic identities through religious participation (Hurh and Kim 1984; Kim and Hurh 1993; Warner 2001). Certainly, the old theory of assimilation no longer proposes an optimal path for the new immigrants in the United States. Yet, the case of Tampa's Korean-American Methodists suggests that the actual process of the alternative assimilation demonstrates their accommodation of the new country's values that help them to engage in the individualistic, democratic American society. The finding of this article also contributes to the growing body of scholarship on recounting the congregational efforts of American Protestantism to mitigate the discordant and destructive aspects of the debate over accommodating LGBTQ members into the denominations.

Funding: This research is funded by the Student Research Award from the Society for the Scientific Study of Religion and the College of Liberal Arts and Social Sciences Dissertation Fellowship from the University of Florida.

Institutional Review Board Statement: The study was conducted according to the guidelines of the Declaration of Helsinki, and approved by the Institutional Review Board (protocol code 201702446 and 14 November 2017).

Informed Consent Statement: Informed consent was obtained from all subjects involved in the study.

Data Availability Statement: Not Applicable.

Conflicts of Interest: The authors declare no conflict of interest.

\section{Notes}

1 The TKUMC, founded in 1974 in the Tampa Bay area by Korean immigrant Methodists, is a predominantly first-generation Korean congregation with about 300 Korean and 50 white and other Asian American lay people. I conducted my ethnographic research between November of 2017 and June of 2019 after the approval of my IRB at the University of Florida in November 2017. I collected such data as weekly periodicals, took notes on pastors' sermons, and conducted informal interviews with church members. From November 2018 to June 2019, I continued my research through in-depth interviews (snowball sampling) with 54 first-generation Korean-American lay members and three ministers. All interviewees were born and raised in Korea and moved to the United States. They all currently hold either U.S. citizenship or permanent residency. Each interview, which took at least two hours, was conducted in the Korean or English languages, depending on their preferences, and employed open-ended questions about their religious experiences in both countries.

2 The scholarship argues that under the Neo-Confucian values such as filial piety, family lineage, and patriarchy, the firstgeneration Korean-American evangelical community takes heterosexual intra-ethnic marriage for granted, while it is further consecrated by the conservative Christian theology grounded in biblical literalism and inerrancy that defines homosexuality as a "religious sin" (Chung et al. 2006; Han 2000; Rhee 2006; Thomsen 2019; Yi et al. 2017).

3 Other mainline Protestant churches, holding their conservative religious teaching on homosexuality, underwent a similar dilemma caused by their progressive political activism in the past few decades. As a result, The Episcopal Church (1994), The United Church of Christ (2005), The Evangelical Lutheran Church (2009), and The Presbyterian Church (USA) (2011) have amended their policies to allow the ordination of LGBTQ members.

4 The interview with Han Myeongsuk.

5 Amy M. Burdette, Christopher G. Ellison, and Terrance D. Hill point out that literal understanding of the Bible is a product of the particular group who share the same social and moral values (Burdette et al. 2005, pp. 192-93). Resonating with this point, Gowoon Jung recounts how Korean evangelical women's anti-homosexuality and LGBT rights rationale is grounded in their conservative Christian theology mashed up with South Korea's neo-Confucian values and nationalism (Jung 2020).

The interview with Gang Minjun.

Jung points out that evangelical women in South Korea similarly concern about the United States, as an "example of the domino effect," whose recent approval of same-sex marriage has caused "social confusion" that challenges the heterosexual normative culture (Jung 2020, pp. 14-16).

8 The interview with Yi Hyeonjeong.

9 The interview with An Seongsu. 
10

The interview with Yi Dongjin.

The interview with Gim Hyeonju.

The interview with Yang Seoyeon.

Hong's columns (26 January 2019 and 2 February 2019).

The interview with Jeong Sukja.

The interview with Jang Yeongsik

The interview with Gim Haeun.

The interview with Yun Jiwon.

The interview with Bak Jeongja.

The interview with Hwang Angela.

\section{References}

Balch, David L. 2000. Homosexuality, Science, and the "Plain Sense of Scripture". Edited by David Balch. Grand Rapids: Eerdmans.

Becker, Penny E. 1999. Congregations in Conflict: Cultural Models of Local Religious Life. Cambridge: Cambridge University Press.

Bellah, Robert N., Richard Madsen, William M. Sullivan, Ann Swidler, and Steven M. Tipton. 1985. Habits of the Heart: Individualism and Commitment in American Life. Berkeley and Los Angles: University of California Press.

Burdette, Amy M., Christopher G. Ellison, and Terrence D. Hill. 2005. Conservative Protestantism and Tolerance toward Homosexuals: An Examination of Potential Mechanisms. Sociological Inquiry 75: 177-96. [CrossRef]

Cadge, Wendy, Heather Day, and Christopher Wildeman. 2007. Bridging the Denomination-Congregation Divide: Evangelical Lutheran Church in America Congregations Respond to Homosexuality. Review of Religious Research 48: 245-59.

Cadge, Wendy, Laura R. Olson, and Christopher Wildeman. 2008. Denominational Resources Influence Debate about Homosexuality in Mainline Protestant Congregations. Sociology of Religion 69: 187-207. [CrossRef]

Chen, Carolyn. 2008. Getting Saved in America: Taiwanese Immigration and Religious Experience. Princeton and Oxford: Princeton University Press.

Choi, Jeyoul. 2021. Negotiating Marginality: The Rise of Religious Individualism in a Korean Methodist Church. Gainesville: University of Florida.

Chung, Grace, Ramona F. Oswald, and Angela Wiley. 2006. Good Daughters: Three Difference Ways of Being Korean American Queer Women. Journal of GLBT Family Studies 2: 101-24. [CrossRef]

De Young, James B. 2000. Homosexuality: Contemporary Claims Examined in Light of the Bible and Other Ancient Literature and Law. Grand Rapids: Kregel.

Di, Di. 2018. Paths to Enlightenment: Constructing Buddhist Identities in Mainland China and the United States. Sociology of Religion 97: 449-71. [CrossRef]

Ebaugh, H. Rose, and J. Saltzman Chafetz. 2000. Religion and the New Immigrants: Continuities and Adaptations in Immigrant Congregations. Walnut Creek: AltaMira Press.

Fulton, Aubyn S., Richard L. Gorsuch, and Elizabeth A. Maynard. 1999. Religious Orientation, Antihomosexual Sentiment, and Fundamentalism among Christians. Journal for the Scientific Study of Religion 38: 14-22. [CrossRef]

Gilbert, Kathy L. 2016a. 3 Gay Pastors Among Nominees for Bishop. United Methodist News. Available online: https://www.umnews. org/en/news/3-gay-pastors-among-nominees-for-bishop (accessed on 6 July 2020).

Gilbert, Kathy L. 2016b. Western Jurisdiction Elects Openly Gay United Methodist Bioship. United Methodist News. Available online: https:/ / www.umnews.org/en/news/western-jurisdiction-elects-openly-gay-united-methodist-bishop (accessed on 6 July 2020).

Gilbert, Kathy L., Heather Hahn, and Joey Butler. 2019. 2019 General Conference passes Traditional Plan. United Methodist News. Available online: https:/ / www.umnews.org/en/news/gc2019-daily-feb-26 (accessed on 6 July 2020).

Grenz, Stanley J. 1998. Welcoming but Not Affirming: An Evangelical Response to Homosexuality. Louisville: Westminster John Knox.

Griffith, Marie. 2017. Moral Combat: How Sex Divided American Christians and Fractured American Politics. New York: Basic Books.

Haas, Guenther. 2002. Perspectives on Homosexuality: A Review Article. Journal of the Evangelical Theological Society 42: 497-512.

Han, Judy J. 2000. Organizing Korean Americans Against Homophobia. Sojourner 25: 1-4.

Hodges, Sam. 2020. Diverse Leaders' Group Offers Separation Plan. United Methodist News. Available online: https://www.umnews. org/en/news/diverse-leaders-group-offers-separation-plan (accessed on 8 July 2020).

Hurh, Won Moo, and Kwang Chung Kim. 1984. Korean Immigrants in America: A Structural Analysis of Ethnic Confinement and Adhesive Adaptation. Rutherford: Fairleigh Dickinson University Press.

Jones, Stanton L., and Mark A. Yarhouse. 2000. Homosexuality: The Use of Scientific Research in the Church's Moral Debate. Downers Grove: InterVarsity.

Jung, G. 2016. Does Transnational Experience Constrain Religiosity? Korean Evangelical Women's Discourse on LGBT Persons. Religions 7: 124. [CrossRef]

Jung, Gowoon. 2020. Evangelical Protestant Women's Views on Homosexuality and LGBT Rights in Korea: The Role of Confucianism and Nationalism in Heteronormative Ideology. Journal of Homosexuality 10: 1-25. [CrossRef] [PubMed]

Kim, Rebecca Y. 2015. The Spirit Moves West: Korean Missionaries in America. Oxford and London: Oxford University Press. 
Kim, Thomas. 2018. Korean United Methodists and Bishops Struggle to Find a Way Forward. United Methodist News. Available online: https://www.umnews.org/en/news/korean-united-methodist-and-bishops-struggle-to-find-a-way-forward (accessed on 24 May 2021).

Kim, Kwang Chung, and Won Moo Hurh. 1993. Beyond Assimilation and Pluralism; Syncretic Sociocultural Adaptation of Korean Immigrants in the U.S. Ethnic and Racial Studies 16: 696-713. [CrossRef]

Kim, Sharon, and Rebecca Y. Kim. 2012. Revival and Renewal: Korean American Protestants Beyond Immigrant Enclaves. Studies in World Christianity 18: 291-312. [CrossRef]

Loftus, Jeni. 2001. America's Liberalization in Attitudes toward Homosexuality, 1973 to 1998. American Sociological Review 66: 762-82. [CrossRef]

Mainstream UMC. 2019. Complete Report of the Commission on the Way Forward. Available online: https://mainstreamumc.com/ documents / WayForwardReports / COWF--p1-93-FullReport.pdf (accessed on 6 July 2020).

Miller, Emily M. 2021. United Methodists Reschedule Meeting-Again and Decision on Splitting-Again. Religion News Service. Available online: https:/ / religionnews.com/2021/02/25/united-methodists-reschedule-meeting-and-decision-on-splittingagain (accessed on 22 May 2021).

Olson, Laure R., and Wendy Cadge. 2002. Talking about Homosexuality: The Views of Mainline Protestant Clergy. Journal for the Scientific Study of Religion 41: 153-67. [CrossRef]

Rhee, Margaret. 2006. Towards Community: KoreAm Journal and Korean American Cultural Attitudes on Same-Sex Marriage. Amerasia Journal 32: 75-88. [CrossRef]

Richey, Russell E., Kenneth E. Rowe, and Jean M. Schmidt. 2010. American Methodism: A Compact History. Nashville: Abingdon Press.

Rogers, Jack. 1999. Biblical Interpretation regarding Homosexuality in the Recent History of the Presbyterian Church (USA). Review of Religious Research 41: 223-38. [CrossRef]

Roof, Wade C., and William McKinney. 1987. American Mainline Religion: Its Changing Shape and Future. New Brunswick: Rutgers University Press.

Smith, Christian S. 1998. American Evangelicalism: Embattled and Thriving. Chicago and London: The University of Chicago Press.

Subhi, Nasrudin, and David Geelan. 2012. When Christianity and Homosexuality Collide: Understanding the Potential Intrapersonal Conflict. Journal of Homosexuality 59: 1382-402. [CrossRef]

Thomsen, Patrick S. 2019. Coming-Out in the Intersections: Examining Relationality in How Korean Gay Men in Seattle Navigate Church, Culture and Family through a Pacific Lens. Journal of Homosexuality 68: 1015-36. [CrossRef]

Van Geest, Fred. 2007. Christian Denominational Political Action on the Subject of Homosexuality. Review of Religious Research 48: 401-19.

Warner, R. S. 1993. Work in Progress toward a New Paradigm for the Sociological Study of Religion in the United States. American Journal of Sociology 98: 1044-93. [CrossRef]

Warner, R. Stephen. 2001. Korean Immigrant Church as Case and Model. In Korean Americans and Their Religions: Pilgrims and Missionaries from a Different Shores. Edited by Ho-Youn Kwon, Kwang Chung Kim and Stephen Warner. University Park: The Pennsylvania State University Press, pp. 25-52.

Wellman, James K., Jr. 1999. Introduction: The Debate over Homosexual Ordination: Subcultural Identity Theory in American Religious Organizations. Review of Religious Research 41: 184-206. [CrossRef]

Wilcox, Melissa M. 2002. When Sheila's a Lesbian: Religious Individualism among Lesbian, Gay, Bisexual, and Transgender Christians. Sociology of Religion 63: 497-513. [CrossRef]

Wink, Walter. 1999. Homosexuality and Christian Faith: Questions of Conscience for the Churches. Edited by Walter Wink. Minneapolis: Fortress.

Wood, James R., and Jon P. Bloch. 1995. The Role of Church Assemblies in Building a Civil Society: The Case of the United Methodist General Conference's Debate on Homosexuality. Sociology of Religion 56: 121-36. [CrossRef]

Yang, Alan S. 1997. Trends: Attitudes Toward Homosexuals. The Public Opinion Quarterly 61: 477-507. [CrossRef]

Yi, Joseph, Joe Phillips, and Shin-Do Sung. 2014. Same-Sex Marriage, Korean Christians, and the Challenge of Democratic Engagement. Society 51: 415-22. [CrossRef]

Yi, Joseph, Gowoon Jung, and Joe Phillips. 2017. Evangelical Christian Discourse in South Korea on the LGBT: The Politics of Cross-Border Learning. Symposium: Sex and Controversy 54: 29-33. [CrossRef]

Yi, Joseph, Gowoon Jung, Saul S. Segura, Joe Phillips, and Jerry Z. Park. 2018. Gay Seouls: Expanding Religious Spaces for NonHeterosexuals in South Korea. Journal of Homosexuality 65: 1457-83. [CrossRef] 